Articles and Essays by David Collier and Richard E. Messick, M. Kent Jennings and Radchard G. Niemi, J. Weinberger, Paul R. Schulman, Fred I. Greenstein, Nancy I. Lieber

\title{
Susan Blackall Hansen
}

Participation, Political Structure, and Concurrence

Austin Sarat and Joel B. Grossman

Courts and Conflict Resolution

Christopher H. Achen

Mass Political Attitudes and the Survey Response

Francisco Arcelus and Allan H. Meltzer, Howard S. Bloom and H. Douglas Price, Saul Goodman and Gerald H. Kramer

Economic Variables and Congressional Elections

Douglas W. Rae, Gordon Tullock

The Limits of Consensual Decision

Published Quarterly by

The American Political Science Association

Vol. LXIX December 1975 No. 4 


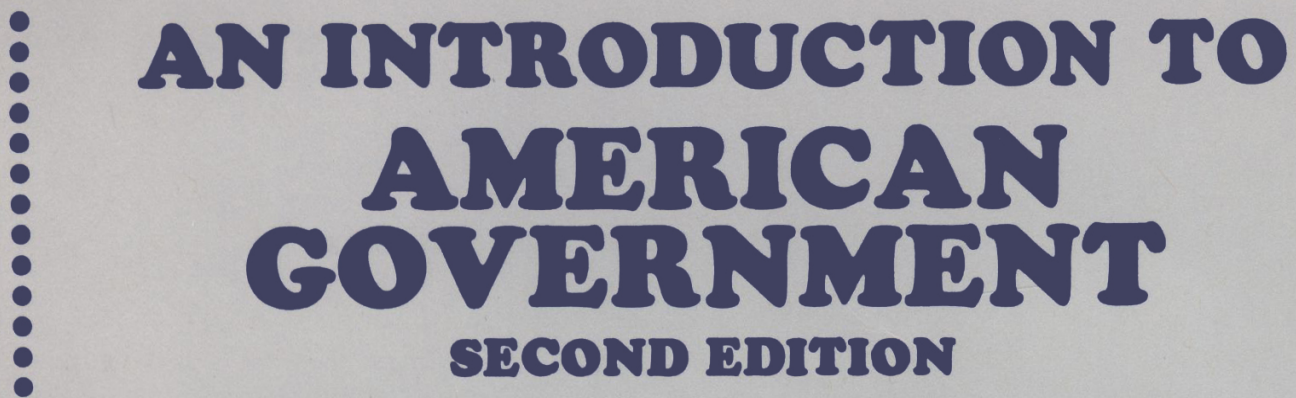

\section{By Kenneth Prewitt and Sidney Verba}

To ensure up-to-date coverage of events and research and to incorporate many users' and reviewers' suggestions, this widely used analysis of the institutional and behavioral aspects of American government has been revised after two years.

Features that made the book an instant success:

- alternative viewpoints on issues

- debates concluding many chapters

- stress on institutions and policy - its makers and benefactors

- three brief discussions of how political scientists discuss politics

- focus on the relationship between capitalism and American democracy

- insightful analyses of recently polarized political attitudes along racial, sexual, and economic lines

- authoritative and easily understood information on which citizens participate - and how - in American political life

And now in the Second Edition:

- more information on how government works

- six new descriptive sections explaining such procedures as how a bill becomes a law

- new material on revenue sharing, the rights of the criminally accused, affirmative action, and other current topics

- Watergate-related illustrations in several discussions

- extensive coverage of recent congressional reforms

- new emphasis on economic issues

- a new chapter on the separation of powers that integrates material from all government branches

- early coverage of the Constitution

- new photographs

February 1976. Tentative: 640 pages; $\$ 11.95$. Student Study Guide. Instructor's Manual.

To request examination copies, write to Lilian Schein, Dept. 155. Please include course title, enrollment, and present text.

10 East 53d Street New York, N.Y. 10022

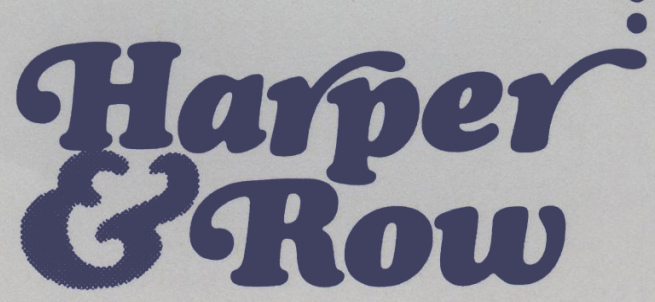




\section{The American Political Science Review}

Vol. LXIX

December $197 \%$

No. 4

\section{CONTENTS}

1177 Editorial Comment

1181 Participation, Political Structure, and Concurrence

Susan Blackall Hansen

1200 Courts and Conflict Resolution: Problems in the Mobilization of Adjudication Austin Sarat and Joel B. Grossman

1218 Mass Political Attitudes and the Survey Response

Christopher H. Achen

1232 The Effect of Aggregate Economic Variables on Congressional Elections

Francisco Arcelus and Allan $\mathrm{H}$. Melizer

1240 Comment

Howard S. Bloom and H. Douglas Price

1255 Comment

Saul Goodman and Gerald H. Kramer

1266 Rejoinder

Francisco Arcelus and Allan H. Meltzer

1270 The Limits of Consensual Decision

Douglas W. Rae

1295 Comment

Gordon Tullock

$1298 \quad$ Rejoinder

Douglas W. Rae

1299 Prerequisities Versus Diffusion: Testing Alternative Explanations of Social Security Adoption

David Collier and Richard E. Messick

1316 Continuity and Change in Political Orientations: A Longitudinal Study of Two Generations

M. Kent Jennings and Richard G. Niemi

1336 Hobbes's Doctrine of Method

J. Weinberger

1354 Nonincremental Policy Making: Notes Toward an Alternative Paradigm

Paul R. Schulman

1371 The Benevolent Leader Revisited: Children's Images of Political Leaders in Three Democracies

Fred I. Greenstein

1399 Communications

1406 Book Reviews and Essays

1406 Politics of the French Left: A Review Essay

Nancy I. Lieber

1539 Index to Volume LXIX

Office of publication: Curtis Reed Plaza, Menasha, Wisconsin.

Second class postage paid at Washington, D.C., and at additional mailing offices.

Printed in the United States of America by George Banta Company, Inc., Menasha, Winconsin.

Copyright, 1976, by The American Political Science Association. 
Effective January 1, 1976, all manuscripts submitted for possible publication in the Review should go to

Professor Charles O. Jones

Department of Political Science, Mervis Hall

University of Pittsburgh

Pittsburgh, Pennsylvania 15260

Correspondence about all issues up to and including the issue of September 1977 should continue to be addressed to the managing editor in Berkeley. 


\section{ARTICLES}

1181 Participation, Political Structure, and Concurrence. Under what circumstances do citizens in a democracy influence their leaders? This paper uses an index of citizen-leader agreement on community problems to examine the effects of political factors on linkage. This index, termed concurrence, was based on parallel questions on community problems asked of citizens, government heads, and other local leaders sampled in sixty-four smaller American communities.

Concurrence was significantly higher in communities with high levels of citizen participation, contested elections, partisan ballots, and active political parties. Regression analysis showed that while voting rates had the largest direct impact on concurrence, participation had more impact when salient electoral alternatives were available. Partisan, contested elections also were associated with higher concurrence between leaders and persons of low socioeconomic status. Political factors also affected concurrence rates in both consensual and nonconsensual communities.

Alternative explanations for these findings (popular control of leaders, leaders' efforts to influence citizens or manipulate participation) are considered. Since concurrence scores of nonelected local leaders were also higher in participant communities with contested elections, it is suggested that political factors may affect citizen-leader agreement by facilitating communication between leaders and citizens, as well as by aiding electoral accountability.

By Susan Blackall Hansen, Assistant Professor of Political Science, University of Illinois, ChampaignUrbana.

1200 Courts and Conflict Resolution: Problems in the Mobilization of Adjudication. This article attempts to assess the role of courts and other adjudicative institutions in the definition, interpretation, and management of conflict. Understanding the function of courts requires an understanding of a society's entire range of conflict management mechanisms. Particular emphasis is placed on those variables most likely to determine where and how conflicts will be solved.

Adjudicative institutions can be effectively differentiated by a typology which measures the level of formality in procedures and the degree of "publicness." The structure of a dispute-resolving institution will have an important effect on which disputes are presented to it and how they are decided. The nature of the dispute, goals of the disputants, social context, and political culture are also important variables.

Government has an important stake in the manner in which disputes arise and are resolved. It may promote or require the resolution of some disputes in the courts while allowing others to be resolved in less public and formal arenas. Formal litigation may provide a model for private dispute resolution. It may also absorb and deflect grievances before they escalate into more organized and intense demands on the political system. Finally, litigation may have an important effect on system stability by promoting support for regime values.

By Austin Sarat, Assistant Professor of Political Science, Amherst College and Joel B. Grossman, Professor of Political Science, University of Wisconsin, Madison.

1218 Mass Political Attitudes and the Survey Response. Students of public opinion research have argued that voters show very little consistency and structure in their political attitudes. A model of the survey response is proposed which takes account of the vagueness in opinion survey questions and in response categories. When estimates are made of this vagueness or "measurement error" and the estimates applied to the principal previous study, nearly all the inconsistency is shown to be the result of the vagueness of the questions rather than of any failure by the respondents.

By Christopher H. Achen, Assistant Professor of Political Science, University of California, Berkeley.

1232 The Effect of Aggregate Economic Variables on Congressional Elections. This paper uses rational voting behavior as an organizing device to develop a framework within which to consider the effect of economic aggregates on voters. Unlike most previous studies, ours permits the voter to vote for candidates of either party or to abstain. A principal finding is that the effect of the main economic aggregates on the participation rate is much clearer than the effects on either party. Our results deny that an incumbent administration can affect the control of Congress by stimulating the economy. Voters appear to make judgments about inflation, unemployment and economic growth. We investigated on the basis of long-term, not short-term performance.

By Francisco Arcelus, Assistant Professor of Economics and Commerce, Simon Fraser University, and Allan H. Meltzer, Maurice Falk Professor of Economics and Social Science, Carnegie-Mellon University.

Comment. By Howaro S. Bloom, Ph.D. Candidate in Political Economy and Government, Harvard University, and H. Douglas Price, Professor of Government, Harvard Univesity.

Comment. By Saul Goodman, L.L.B. Candidate, University of Virginia Law School and Gerald H. Kramer, Professor of Political Science, Yale University.

Rejoinder. By Francisco Arcelus and Allan H. Meltzer. 
1270 The Limits of Consensual Decision. This essay criticizes the ideal of consensual decision as it appears in liberal political theory. A historical survey begins with Locke's view of consent, its criticism and extension by 19 th century figures such as Godwin, Calhoun, and Mill, its reappearance in the guise of economic efficiency within the works of Wicksell or Buchanan and Tullock and as moral autonomy in Wolf"s Defense of Anarchy. The paper offers a structural account of political decision making in which vulnerability to the authority of others seems inescapable and in which neither unanimity nor a universal right of consent is possible. On this telling, consensual decision is logically unattainable and misdirects constitutional theory.

By Douglas W. Rae, Professor of Political Science, Yale University.

Comment. By Gordon Tullock, University Professor, Virginia Polytechnic Institute and State University.

Rejoinder. By Douglas W. Rae.

1299 Prerequisites Versus Diffusion: Testing Alternative Explanations of Social Security Adoption. Cross-national research has, with a few exceptions, dealt exclusively with hypotheses that focus on causal relations within nations. It is increasingly clear both on substantive and methodological grounds, however, that diffusion effects among nations must also be considered. The present research combines these alternative perspectives in an analysis of the timing of the first adoption of social security in nations. It is found that not only prerequisites explanations-which focus on causes within each nation-but also spatial and hierarchical diffusion effects must be considered in explaining patterns of social security adoption. The most important overall pattern, which appears to result from diffusion, is the tendency for later adopters to adopt at lower levels of modernization. This finding is interpreted as being due in part to a general tendency toward a larger role of the state in later developing countries-involving an important difference in the sequence in which different aspects of modernization occur-and in part to special characteristics of social security as a public policy.

By David Collrer, Associate Professor of Political Science, Indiana University, and Richard E. Messick, Research Assistant, Energy Policy Research Project, George Washington University.

1316 Continuity and Change in Political Orientations: a Longitudinal Study of Two Generations. This paper utilizes a national panel study of two biologically linked generations to study political change and continuity between 1965 and 1973. Four basic processes and combinations thereof are posited: absolute continuity, generational effects, life-cycle effects, and period effects. Data at the aggregate level give strong support for each type of change and continuity progression, depending upon the substantive political orientation examined. There are also strong traces of hybrid effects, especially the combination of period and life-cycle processes acting to propel the younger generation at a faster clip than the older. Over the eight-year span the absolute cleavage between the generations tended to decline, the major exception occurring with respect to specific issues and partisanship. The anomaly of this strain toward convergence in the light of the generation gap controversy is discussed.

By M. Kent Jennings, Professor of Political Science and Program Director, Center for Political Studies, University of Michigan, and Richard G. Nieml, Professor of Political Science, University of Rochester.

3236 Hobbes's Doctrine of Method. A persistent problem in the interpretation of Hobbes's self-proclaimed founding of modern political science is the nature of the link between that political science and Hobbes's understanding of modern natural science and scientific method. The intention of this essay is to suggest that Hobbes's doctrine of method reveals the unity of his teaching about science, man, and politics. The unifying role of the doctrine of method can be understood only as a function of Hobbes's intention to reform what he saw as the previously defective relationship between practice and theory. In the light of this intention, the doctrine of method will be shown to consist in a new rhetoric which links the resolution of the human problem to the conquest of nature facilitated by the new science of nature. This rhetoric will be shown to be the substantial core of the doctrine of method itself.

By J. Weingerger, Assistant Professor of Political Science, Michigan State University.

1354 Nonincremental Policy Making: Notes Toward an Alternative Paradigm. Much of the literature of policy analysis and public administration is dominated by incremental and "divisible goods" paradigms. Policy is assumed to be a process of marginal and adjustive decision making in which benefits are dispensed piecemeal-proportionate to prevailing distributions of power or publicized need. This essay asserts the existence of a class of nonincremental, indivisible policy pursuits for which the analytical weaponry of political science is largely inappropriate. Such policies display a distinctive set of political and administrative characteristics. These characteristics are explained and examined in connection with manned space exploration policy. An assessment is offered of the challenges posed by nonincremental policy to contemporary outlooks in political science.

By Paul R. Schulman, Assistant Professor of Political Science, University of Tennessee. 
1371 The Benevolent Leader Revisited: Children's Images of Political Leaders in Three Democracies. This analysis of open-ended interviews conducted in 1969-70 with small samples of English, French, and white and black American children focuses on orientations toward the heads of state of the three nations and the Prime Ministers of Britain and France. The English children exhibit remarkably positive views of the Queen. Many of them believe her to be the nation's effective leader rather than a figurehead. Any political animus they express is directed toward the Prime Minister. The French children tend to describe the President of the Republic positively when they express feelings toward him at all but expect him to behave harshly and arrogantly in actual situations. Their descriptions of political leaders exude authoritarian imagery and perceptions; they perceive the President of the Republic in an impersonal, undifferentiated manner, and are only barely aware of the Premier. The general descriptions of the President of the United States by white American children interviewed in 1.969-70 are remarkably similar to the benevolent-leader perceptions of children in the Eisenhower-Kennedy years, but the 1969-70 children exhibit much less idealized views of a president depicted as a law-breaker. A post-Watergate white American comparison group interviewed in June 1973 is generally aware of, but puzzled by, the Watergate events. At this early stage in the Watergate revelations, white children were only slightly less likely than the 1969-70 respondents to idealize the President, but were substantially more likely to perceive the president depicted as a law-breaker in terms implying that the President is "above the law." The American black comparison group, which is too small and special in its geographical circumstances to offer more than suggestive findings, is the most negative of the four groups in general responses to the head of state, but is more like the white American group than like the English or French children in expectations about the actual behavior of the leader. Even though the black and white American children seem to be similar in their expectations about how certain political encounters would ensue, interpretations of encounters are strikingly different.

By Fred I. Greenstein, Henry Luce Professor of Politics, Law, and Society, Princeton University.

1399 COMMUNICATIONS

From Richard G. Hutcheson III, Jerome R. Corsi, Peter G. Stillman, Wallace J. Thies, Jack Woddis, Bernard S. Morris, David R. Godschalk, Judith V. May

\section{BOOK REVIEWS AND ESSAYS}

Politics of the French Left: A Review Essay. Jean-Marie Borzeix, Mitterrand lui-même Pierre Guidoni, Histoire du nouveau parti socialiste; André Laurens and Thierry Pfister, Les nouveaux communistes; Georges Marchais, Le Défi démocratique; Francois Mitterrand, La Rose au poing; Francois Mitterrand, Ma part de vérité, Didier Motchane, Clefs pour le socialisme; Programme commun de gouvernement: Parti socialiste, Parti communiste, Mouvement des radicaux de gauche.

By Nancy I. Lieber, Lecturer in Political Science, University of California, Davis.

1420 Political Theory, History of Political Thought and Methodology

Evan Bitsaxis, Welfare Versus Freedom. William M. Leiter, p. 1420

Nikolai Bukharin, Historical Materialism: A System of Sociology; Nikolai Bukharin, Imperialism and World Economy; N. Bukharin and E. Preobrazhensky, The ABC of Communism (1966 edition); and N.

Bukharin and E. Preobrazhensky, The ABC of Communism (1969 edition). Stephen F. Cohen, p. 1421 Richard Gombin, Les Origines du Gauchisme. Roy Pierce, p. 1423

Z. A. Jordan, The Evolution of Dialectical Materialism: A Philosophical and Sociological Analysis. Timothy O'Hagan, p. 1424

Allen C. Kelley, Jeffrey G. Williamson, and Russell J. Cheetham, Dualistic Economic Development: Theory and History. Gustav Ranis, p. 1425

Hans Kelsen, The Pure Theory of Law; and Hans Kelsen, What is Justice: Justice, Law, and Politics in the Mirror of Science. H. W. Harris, p. 1427

Lennart Lundquist, Means and Goals of Political Decentralization. Karl W. Deutsch and Manfred Kochen, p. 1429

Francis E. Mineka, ed., The Earlier Letters of John Stuart Mill, 1812-1848; and Francis E. Mineka and Dwight N. Lindley, eds., The Later Letters of John Stuart Mill, 1849-1873. Joseph Hamburger, p. 1430 Claus Mueller, The Politics of Communication: $A$ Study in the Political Sociology of Language, Socialization, and Legitimation. Murray Edelman, p. 1432

T. L.S. Sprigge, ed. (Vols. I and II) and I. R. Christie, ed. (Vol. III), The Correspondence of Jeremy Bentham. Ian Budge, p. 1433

Ross Terrill, $R$. H. Tawney and His Times. Alan Ryan, p. 1435

Heinrich Winnik, Rafael Moses, and Mortimer Ostow, Psychological Bases of War. John Gunn, p. 1436

1437 American Government and Politics

Henry J. Aaron, Shelter and Subsidies: Who Benefits from Federal Housing Policies? and R. Robert Linowes and Don T. Allensworth, The Politics of Land Use: Planning, Zoning, and the Private Developer. and Joseph L. Stevens, p. 1437

The American Political Science Association, Political Science and State and Local Gocernment. Ira Sharkansky, p. 1439 
Leland D. Baldwin, Reframing the Constitution: An Imperative for Modern America) Carl Baar, p. 1439

Jewel Bellush and Stephen M. David, Race and Politics in New York City: Five Studies in Policy-making. Paul Kantor, p. 1440

Richard Burt and Geoffrey Kemp, eds., Congressional Hearings on American Defense Policy, 1947-1971: An Annotated Bibliographv. William I. Bacchus, p. 1441

The Citizens Conference on State Legislatures, State Legislatures: An Evaluation of Their Effectiveness. William J. Keefe, p. 1442

Joon Chien Doh, The Planning-Programming-Budgeting System in Three Federal Agencies. Allan Schick, p. 1443

Anthony Downs, Opening Up the Suburbs: An Urban Strategy for America. Harlan Hahn, p. 1444

Julius Goebel, Jr., The Oliver Wendell Holmes Devise History of the Supreme Court of the United States, Vol. I, Antecedents and Beginnings to 1801. David Fellman, p. 1445

Harlan Hahn, Urban-Rural Conflict: The Politics of Change, C. Edwin Gilmour, p. 1447

L. G. Hines, Environmental Issues: Pollution and Economics; and E. F. Schumacher, Small is Beautiful: Economics as if People Mattered. Harold Sprout, p. 1448

James Willard Hurst, The Law of Treason in the United States: Collected Essays. Marvin R. Summers, p. 1449

Samuel Krislov, Keith O. Boyum, Jerry N. Clark, Roger C. Schaefer, and Susan O. White, eds., Compliance and the Law: A Multi-Disciplinary Approach. Joel B. Grossman, p. 1450

Seymour Martin Lipset, Rebellion in the University. Philip G. Altbach, p. 1452

David Price, Who Makes the Laws? John F. Manley, p. 1453

Donald L. Robinson, Slavery in the Structure of American Politics, 1765-1820. Edgar J. McManus, p. 1454

Charles Sackrey, The Political Economy of Urban Poverty. Seymour Z. Mann, p. 1455

David Curtis Skaggs, Roots of Maryland Democracy, 1753-1776. David A. Bohmer, p. 1456

Robert Sobel, The Age of Giant Corporations: A Microeconomic History of American Business, 1914-1970. Jonathan Hughes, p. 1457

Stephen P. Strickland, Politics, Science, and Dread Disease: A Short History of United States Medical Research Policy. Jerry L. Weaver, p. 1458

Martin and Susan Tolchin, To The Victor ... . Political Patronage From the Clubhouse to the White House. James E. Piereson, p. 1459

Joseph S. Wholey et al, Federal Evaluation Policy: Analyzing the Effects of Public Programs. Joel R. Dickinson, p. 1460

1461 Comparative Government and Politics

Weston H. Agor, ed., Latin American Legislatures: Their Role and Influence, Analyses for Nine Countries. Kenneth L. Karst, p. 1461

Robert J. Alexander, Aprismo: The Ideas and Doctrines of Victor Raúl Haja de la Torre. Harry Kantor, p. 1462

Oton Ambroz, Realignment of World Power: The Russo-Chinese Schism Under the Impact of Mao Tsetung's Last Revolution, Vols. I and II. Gaston J. Sigur, p. 1463

Harvey A. Averch, John E. Koehler, and Frank H. Denton, The Matrix of Policy in the Philippines. Mohd. A. Nawawi, p. 1464

Henry Barbera, Rich Nations and Poor in Peace and War. Arthur S. Banks, p. 1465

Gordon A: Bennett and Ronald N. Montaperto, Red Guard: The Political Biography of Dai Hsiao-ai. Sheldon Appleton, p. 1466

R. M. Berndt and P. Lawrence, eds., Politics in New Guinea. Peta Colebatch, p. 1467

Jean Blondel, Comparative Legislatures. Lawrence C. Dodd, p. 1469

C. Ernest Dawn, From Ottomanism to Arabism: Essays on the Origins of Arab Nationalism. William L. Cleveland, p. 1470

William Derman, Serfs, Peasants and Socialists: A Former Serf Village in the Republic of Guinea. Victor D. Du Bois, p. 1471

Mark Elvin, The Pattern of the Chinese Past. Marianne Bastid, p. 1472

Marcus F. Franda, Radical Politics in West Bengal. Ashis Nandy, p. 1473

Andre Gunder Frank, Lumpenbourgeoisie and Lumpendevelopment: Dependency, Class and Politics in Latin America. Arturo Valenzuela, p. 1475

Martin Harry Greenberg, Bureaucracy and Development: A Mexican Case Study, Clarence E. Thurber, p. 1476

Paul M. Hayes, Quisling: The Career and Political Ideas of Vidkun Quisling, Thomas Chr. Wyller, p. 1477

Franz- Wilhelm Heimer, ed., Social Change in Angola. Ronald H. Chilcote, p. 1478

Francis G. Hutchins, India's Revolution: Gandhi and the Quit India Movement, Raghavan Iyer, p. 1479

Doreen Ingrams, compiler and annotator, Palestine Papers, 1917-1922: Seeds of Conflict. Norman Rose, p. 1480

Fuad Jabber, Israel and Nuclear Weapons: Present Options and Future Strategies. Jacob Reuveny, p. 1481 Naum Jasny, Soviet Economists of the Twenties: Names to be Remembered. Alfred Zauberman, p. 1482

Katherine Marshall Johnson, Urban Government for the Prefecture of Casablanca. Remy Leveau, p. 1483 Ilpyong J. Kim, The Politics of Chinese Communism: Kiangsi under the Soviets. Albert Feuerwerker, p. 1484 Jeanne Kirkpatrick, Leader and Vanguard in Mass Society: A Study of Peronist Argentina. David C. Jordan, p. 1485 
Leo Kuper and M. G. Smith, eds., Pluralism in Africa. Okwudiba Nnoli, p. 1486

Roger Lumley, White-Collar Unionism in Britain. David Coates, p. 1487

Adrian Lyttelton, The Seizure of Power: Fascism in Italy, 1919-1929. Roland Sarti, p. 1488

J. Michael Mahar, ed., The Untouchables in Contemporary India. W. H. Morris-Jones, p. 1489

Ellen Mickiewicz. ed., Handbook of Soviet Social Science Data. William A. Welsh, p. 1490

Alfred Morris, The Growth of Parliamentary Scrutiny by Committee: A Symposium. Lyndelle D. Fairlie, p. 1493

Lutz Niethammer, Entnazifzierung in Bayern: Säuberung und Rehabilitierung unter Amerikanischer Besatzung. C. Bradley Scharf, p. 1494

Richard F. Nyrop, John Duke Anthony, Beryl Lieff Benderly, William W. Cover, Newton B. Parker, and Suzanne Teleki, Area Handbock for Algeria. Clement Henry Moore, p. 1495

Karl J. Pelzer, West Malaysia and Singapore: A Selected Bibliography. Robert O. Tilman, p. 1496

Nageshwar Prasad, Decentralisation in Yugoslavia and India. A. H. Somjee, p. 1496

Robert Presthus, Elite Accommodation in Canadian Politics. John C. Courtney, p. 1497

R. M. Punnett, Front-Bench Opposition: The Role of the Leader of the Opposition, the Shadow Cabinet and the Shadow Government in British Politics. Jorgen S. Rasmussen, p. 1499

Alvin Rabushka, Race and Politics in Urhan Malaya. Felix Gagliano, p. 1500

W. W. Rostow, Politics and the Stages of Growth. Ronald Rogowski, p. 1501

Philippe C. Schmitter, ed., Military Rule in Latin America: Functions, Consequences and Perspectives. Liisa North, p. 1502

Benjamin I. Schwartz, ed., Reflections on the May Fourth Movement. T. K. Tong, p. 1504

Robert Jones Shafer, Mexican Business Organizations: History and Analysis. Robert T. Aubey, p. 1505

Mauricio Solaun and Michael Quinn, Sinners and Heretics: The Politics of Military Intervention in Latin America. John S. Fitch III, p. 1506

David Joel Steinberg. David Wyatt. John R. W. Smail, Alexander Woodside, Tom R. Roff, and David P. Chandler, In Search of Southeast Asia: A Modern Historv. Cecil Hobbs, p. 1507

Jürg Steiner, ed. with Erwin Bucher, Daniel Frei and Leo Schürmann, Das Politische System der Schweiz. Benjamin R. Barber, p. 1508

Seymour Topping, Journev Between Two Chinas. June Teufel Dreyer, p. 1510

Martin L. Van Creveld, Hitler's Strategy, 1940-1941: The Balkan Clue. Dan P. Silverman, p. 1511

Sidney Verba, Bashiruddin Ahmed, and Anil Bhatt, Caste, Race and Politics: A Comparative Study of India and the United Stares. Richard P. Taub, p. 1511

Svetozar Vukmanovic [Tempo], Revolucija Koja Teče-Memoari [Memoirs on a Flowing Revolution]. Milos Martic, p. 1514

Dov Weintraub, Miriam Shapiro, and Belinda Aquino, Agrarian Development and Modernization in the Philippines. John E. Koehler, p. 1515

Alexander Barton Woodside, Vietnam and the Chinese Model: A Comparative Study of Vietnamese and Chinese Government in the First Half of the Nineteenth Century. Gareth Porter, p. 1516

Jen Yu-wen, The Taiping Revolutionary Movement. Eugene Boardman, p. 1517

\section{International Politics, Law and Organization}

Raymond Aron, The Imperial Republic. Paul Seabury, p. 1518

Dennis L. Bark, Die Berlin-Frage, 1949-1955; and Hans Herzfeld, Berlin in der Weltpolitik, 1945-1970. Richard L. Merritt, p. 1520

James Barros, The League of Nations and the Great Powers: The Greek-Bulgarian Incident, 1925. R. P. Barston, p. 1522

Donald T. Fox, ed., The Cambodian Incursion-Legal Issues. Burns H. Weston, p. 1522

Laszlo Gorgey, Bonn's Eastern Policy, 1964-1971. Gerald Freund, p. 1523

Michael Haas, International Organization: An Interdisciplinary Bibliography. W. Andrew Axline, p. 1525

Baymirza Hayit, Turkestan zwischen Russland und China. George Alexander Lensen, p. 1525

Michael H. Hunt, Frontier Defense and the Open Door: Manchuria in Chinese-American Relations, 18951911. Warren I. Cohen, p. 1526

Aaron S. Klieman, Foundations of British Policy in the Arab World: The Cairo Conference of 1921. Howard M. Sachar, p. 1527

Bruce Kuklick, American Policy and the Division of Germany: The Clash with Russia over Reparations. John W. Keller, p. 1528

Charles Melchior de Molènes, L'Europe de Strasbourg: Une première expérience de parlementarisme international. D. Bruce Marshall, p. 1530

I. W. Moomaw, The Challenge of Hunger: A Program for More Effective Foreign Aid; and Gunnar Myrdal, The Challenge of World Poverty: A World Anti-Poverty Program in Outline. Richard L. Clinton, p. 1531

Robert E. Osgood et al, Retreat from Empire? The First Nixon Administration. H. Bradford Westerfield, p. 1533

Bruce M. Russett, ed., Peace, War, and Numbers. George Modelski, p. 1534

I. M. Sinclair, C. M. G., The Vienna Convention on the Law of Treaties. Gerard J. Mangone, p. 1536

Herbert K. Tillema. Appeal to Force: American Military Intercention in the Era of Containment. Stephen J. Cimbala, p. 1537 
The American Political Science Review, published quarterly during the months of March, June, September, and December, is supplied to all APSA members. Membership dues are charged according to the following schedule:

$\begin{array}{lr}\text { Membership Category } & \text { Dues } \\ \text { Regular } & \\ \text { Annual income } & \$ 20 \\ \text { Under } 12,000 & \$ 25 \\ \$ 12,000-\$ 15,000 & \$ 30 \\ \text { Over } \$ 15,000 & \$ 10 \\ \text { Student and Retired } & \$ 5 \\ \text { Family } & \$ 1000 \\ \text { Life } & \$ 50\end{array}$

Student memberships are limited to five years per person. Foreign currency at the official exchange rate will be accepted for foreign subscriptions and foreign membership fees. The equivalent of $\$ 1$ for additional postage should be added for foreign subscriptions.

Current issues are priced at $\$ 10.50$ per copy; for back issues prior to 1968 address Walter J. Johnson, Inc., 355 Chestnut St., Norwood, New Jersey 07648; for issues 1968 and later send request directly to the Ameriican Political Science Association.

Applications for membership, orders for the Review, and remittances should be addressed to the Executive Director, The American Political Science Association, 1527 New Hampshire Ave., N.W., Washington, D.C. 20036. Notices of changes of address should be received in the Washington office by the 25 th day of the months before publication.

\section{INSTRUCTIONS TO CONTRIBUTORS}

Address correspondence about contributions to the Review concerning issues before the issue of September 1977 to Nelson W. Polsby, Department of Political Science, University of California, Berkeley, Berkeley, California, 94720, and issues after September 1977 (including all new manuscripts) starting January 1, 1976, to Charles O. Jones, Department of Political Science, Mervis Hall, University of Pittsburgh, Pittsburgh, Pennsylvania 15260. Each manuscript should be accompanied by an abstract of up to 150 words briefly describing the article's contents. All manuscripts and abstracts should be submitted IN DUPLICATE. They should be double-spaced and may be in typed, mimeographed, hectographed, or other legible form. Footnotes should appear at the end of the manuscript, not at the bottom of the page, and should also be double-spaced. Manuscripts that do not follow this format will be returned to the authors for retyping.

Since manuscripts are sent out anonymously for editorial evaluation, the author's name and affiliations should appear only on a separate covering page. All footnotes identifying the author should also appear on a separate page.

Address books intended for review to Philip Siegelman, American Political Science Review, 210 Barrows Hall, University of California, Berkeley, Berkeley, California 94720 . Information, including News and Notes, for the Association's newsjournal, PS, should be sent to 1527 New Hampshire Avenue, N.W., Washington, D.C. 20036; advertising, reprint and circulation correspondence should be sent to the Executive Director at the Washington office. Domestic claims for non-receipt of issues must be made within six months of the month of publication; overseas claims, one year. Advertising information and rates are available from Nancy Edgerton, Adv. Manager, APSA, 1527 New Hampshire Avenue, N.W., Washington, D.C. 20036.

Articles and notes appearing in the Review before the June, 1953 issues were indexed in The Reader's Guide to Periodical Literature. Current issues are indexed by The International Political Science Abstracts and the Social Sciences and Humanities Index. Microfilm of the Review, beginning with Volume 1, may be obtained from University Microfilms, 313 North First Street, Ann Arbor, Michigan 48106. A Cumulative Index of the Review, Volumes 1-62: 1906-1968, may also be obtained from University Microfilms. Articles appearing in the Review are listed regularly in ABC Pol Sci and Current Contents: Behavioral, Social \& Management Sciences. Book reviews are indexed in Book Review Index. 